\title{
PENGUATAN SOCIAL AWARENESS DAN OPTIMALISASI PENERAPAN PROTOKOL KESEHATAN PADA ERA NEW NORMAL MELALUI "PROGRAM PELITA"
}

\author{
Noviani Achmad Putri ${ }^{\bowtie}$, Fredy Hermanto, Asep Ginanjar, Aisyah Nur Sayidatun \\ Nisa, Afif Abdan Shakuro, Deni Listiyo, Alifia Putri Tisa Fandilah
}

Social Sciense Education Department, Faculty of Social Science, Universitas Negeri Semarang

\begin{tabular}{l}
\hline Info Artikel \\
\hline Sejarah Artikel: \\
Disubmit: Oktober 2021 \\
Direvisi: November 2021 \\
Diterima: November \\
2021 \\
\hline Keywords: \\
Social Awareness; Health \\
Protocol; Pelita Program \\
\hline
\end{tabular}

\begin{abstract}
Abstrak
Jumlah kasus positif Covid-19 di Indonesia belum sepenuhnya tuntas. Berbagai kebijakan terus diberlakukan dalam upaya preventif untuk menekan penyebaran virus. Akan tetapi masih banyak masyarakat yang belum sepenuhnya mematuhi protokol kesehatan, salah satunya masyarakat di wilayah Tambakrejo Semarang. Hal ini disebabkan kurangnya literasi edukasi protokol kesehatan dan rendahnya social awareness. Oleh karena itu, dibutuhkan upaya preventif bagi masyarakat melalui program "PELITA" (Pendekatan Lingkungan Kita) dimana program ini memberikan pengetahuan tentang kebiasaan adaptasi baru, protokol kesehatan, serta penguatan social awareness. Metode yang digunakan pada program ini yaitu PRA (Participatory Rural Appraisal). Hasil dari program ini berupa penguatan social awareness dan optimalisasi protokol kesehatan pada era new normal yang meliputi sosialisasi kebijakan, edukasi $5 \mathrm{M}$, video tutorial protokol kesehatan, optimasliasi media sosial, giat kampanye, dan kemitraan.
\end{abstract}

\begin{abstract}
The number of positive cases of Covid-19 in Indonesia has not been fully completed. Various policies continue to be implemented in preventive efforts to suppress the spread of the virus. However, there are still many people who do not fully comply with health protocols, one of which is people in the Tambakrejo area, Semarang. This is due to the lack of literacy in health protocol education and low social awareness. Therefore, preventive efforts are needed for the community through the "PELITA" (Pendekatan Lingkungan Kita) program where this program provides knowledge about new adaptation habits, health protocols, and strengthening social awareness. The method used in this program is PRA (Participatory Rural Appraisal). The results of this program are strengthening social awareness and optimizing health protocols in the new normal era which include policy socialization, 5Meducation, video tutorials on health protocols, optimization of social media, active campaigns, and partnerships.
\end{abstract}

(C) 2021 Universitas Negeri Semarang

\footnotetext{
Alamat korespondensi:

Gedung C1 Lantai 1 Program Studi Pendidikan IPS FIS UNNES

Kampus Sekaran, Gunungpati, Semarang, 50229

E-mail: noviani.ips@mail.unnes.ac.id.
}

ISSN 2252-7133

E-ISSN 2548-4648 


\section{PENDAHULUAN}

Pandemi Covid 19 merupakan salah satu dari sekian banyak masalah global yang mempengaruhi kehidupan warga negara di seluruh dunia. Lebih lanjut dampak dari Covid tersebut juga mempengaruhi segala aspek kehidupan baik sosial budaya, ekonomi, politik dan aspek lainnya. Tren kasus covid-19 saat ini sedang mengalami penurunan, hal ini dapat dilihat dari banyaknya wilayah Kabupaten/Kota yang sudah masuk PPKM (Pemberlakuan Pembatasan Kegiatan Masyarakat) pada level 1 serta angka positivity rate nasional berada di bawah 2\%. Akan tetapi, jika melihat dari perjalanan kasus covid-19, dimana kasus positif akan meningkat pasca libur panjang seperti libur hari raya.

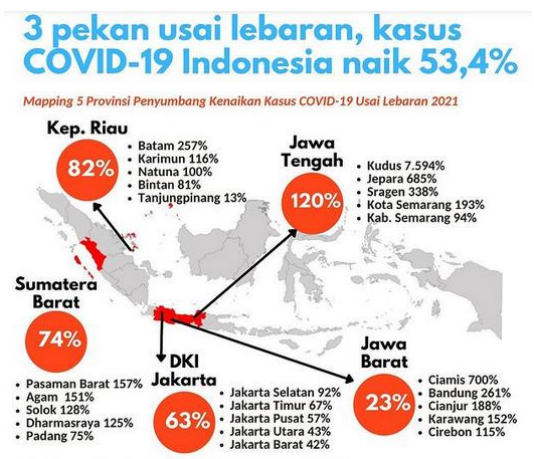

Gambar 1. Kasus Covid-19 Pasca Hari Raya Sumber: Kompas

Berdasarkan gambar 1 dapat diketahui pasca hari raya kasus covid-19 mengalami peningkatan yang signifikan, khusus untuk daerah Jawa Tengah peningkatan kasus covid-19 mencapai $120 \%$. Hal ini menunjukkan bahwa masih banyak masyarakat yang belum sepenuhnya mematuhi protokol kesehatan terutama ketika beraktivitas pada saat liburan. Melihat contoh kasus tersebut, Indonesia beberapa saat lagi akan memasuki masa liburan Hari Raya Natal dan Tahun Baru, dimana aktivitas dan mobilitas masyarakat akan meningkat, tentunya hal ini akan meningkatkan kasus covid-19. Untuk itu dibutuhkan upaya preventif bagi masyarakat melalui program "PELITA" (Pendekatan Lingkungan Kita) dimana program ini memberikan pengetahuan tentang kebiasaan adaptasi baru, protokol kesehatan, serta penguatan social awareness. Program ini dilaksanakan di salah satunya wilayah di Jawa Tengah di Kota Semarang yaitu wilayah Tambakrejo. Pemilihan lokasi ini berdasarkan pada kondisi masyarakat Tambakrejo yang masih banyak mengalami keterbatasan dana, keterbatasan pengetahuan, keterbatas teknologi, sarana dan prasarana. Masyarakat khususnya anak-anak di Tambakrejo masih banyak yang tidak dapat mengakses internet sehingga membuat mereka tidak dapat mengakses informasi terkini. Berdasarakan kondisi anak-anak dan masyarakat yang ada di Tambakrejo menjadi dasar pengabdian ini layak dan mendesak untuk dilakukan tentunya dengan penggunaan tata aturan yang ketat dan disiplin yang tinggi. Program ini tidak hanya bertujuan untuk mengoptimalkan penerapan Protokol Kesehatan saja melainkan juga penguatan Social Awareness bagi warga masyarakat setempat khususnya di masa pandemi sekarang ini. Socialawareness adalah salah satu istilah dan bagian dari domain kompetensi sosial (personal comptenece) yang merupakan bentuk usaha individu dalam memahami dan mengerti bagaimana membangun sebuah hubungan secara emosional dengan orang-orang yang berada disekitarnya tanpa memandang golongan dan latar belakang mereka (Martin, 2017). Hal ini berhubungan dengan indikator Social Awareness yakni 1) empati, dimana seseorang mengerti perasaan orang lain, memahami berbagai perspektif mereka, dan berpartisipasi aktif dalam setiap topik yang dibahas, 2) keasdaran berorganisasi, menelisik apa yang sedang terjadi, menentukan pola jaringan, dan bagaimana mengatur pada level kelompok atau tim, dan 3) mengenali satu sama lain dan sling mengetahui kebutuhan agar tujuan tercapai (Goleman, 1998).

\section{METODE}

Mengacu pada hasil pemetaan masalah yang dihadapi, kebutuhan, dan diskusi penentuan prioritas permasalahan pada masyarakat Tambakrejo Semarang, maka metode pada kegiatan ini yaitu PRA (Participatory Rural Appraisal). PRA merupakan sekelompok pendekatan atau metode yang memungkinkan masyarakat desa untuk saling berbagi, meningkatkan, dan menganalisis pengetahuan mereka tentang kondisi dan 
kehidupan desa, serta membuat rencana dan tindakan nyata (Chambers, 1996). Gambar 2 berikut ini adalah metode dalam pelaksanaan PRA:

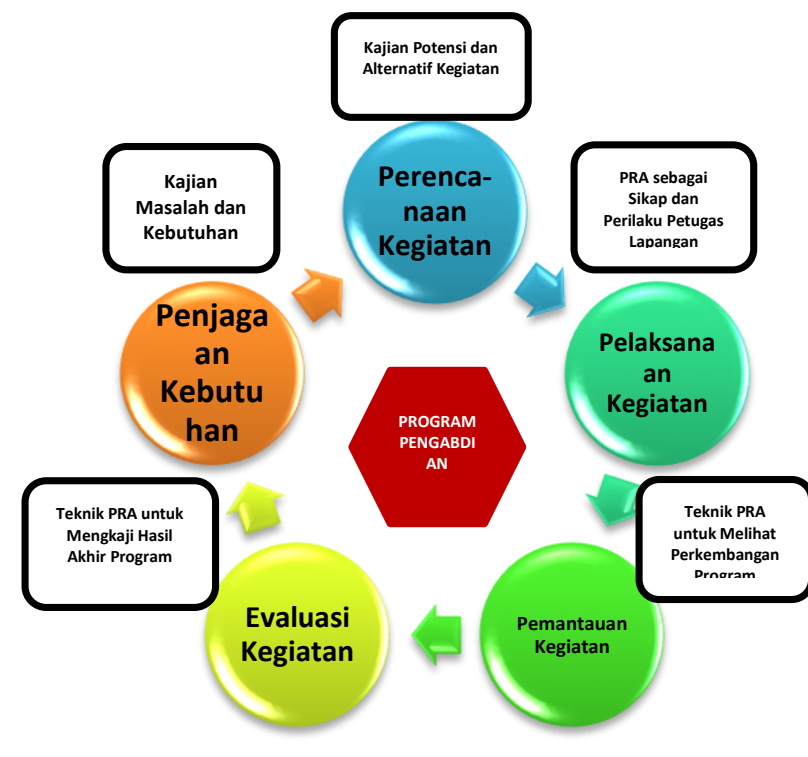

Gambar 2. Metodelogi Pelaksanaan Kegiatan Pengabdian Pada Masyarakat
Beberapa prinsip dasar yang harus dipenuhi dalam metode PRA yaitu saling belajar dan berbagi pengalaman, keterlibatan semua anggota kelompok dan informasi, orang luar sebagai fasilitator, konsep triangulasi, serta optimalisasi hasil, orientasi praktis dan keberlanjutan program (Rochdyanto, 2000). Metode PRA memiliki teknis-teknis yang dijabarkan cukup operasional dengan konsep bahwa keterlibatan masyarakat sangat diperlukan dalam seluruh kegiatan. Pendekatan PRA bertujuan supaya masyarakat menjadi peneliti, perencanaan, dan pelaksanaan pembangunan dan bukan sekedar obyek pembangunan. Penerapan pendekatan dan teknik PRA dan prinsip metode inilah yang dirasa sesuai untuk diterapkan kedalam kegiatan pengabdian ini.

Rincian prosedur kegiatan pengabdian dapat dilihat pada tabel 1 berikut.

Tabel 1. Rincian Prosedur Kerja Kegiatan Pengabdian Kepada Masyarakat

\begin{tabular}{ll}
\hline Prosedur Kerja Kegiatan & \multicolumn{1}{c}{ Rincian Kegiatan yang Dilakukan } \\
\hline Sosialisasi Kebijakan & Pelaksanaan sosialisasi kepada warga tentang: \\
& - Panduan adabtasi kebiasaan baru di Era New Normal \\
& - Kepmenkes No: HK.01.07/Menkes/382/2020 tentang Protokol \\
& Kesehatan di Tempat dan Fasilitas Umum, ada pengaturan tentang \\
& Penertiban dan Pengawasan. \\
\hline Edukasi 5 M & Memberikan materi tentang implementasi Strategi 5M yakni \\
& - Memakai masker, \\
& - Menjaga jarak, \\
& - Mencuci tangan, \\
& - Mengurangi mobilitas interaksi, dan \\
& - Menghindari kerumunan. \\
\hline Video Tutorial Protokol & Memproduksi video tutorial: tentang cara mencuci tangan yang benar, \\
Kesehatan & membuat masker non medis, membuat disinfektan, membuat \\
& handsanitizer dan membuat ember tempat cuci tangan \\
\hline Optimalisasi Sosial Media & - Sarana edukasi dan transfer informasi dan pengetahuan tentang \\
& Protokol Kesehatan (5 M) \\
& - Instagram, Facebook, Twitter, Youtube, dll. \\
\hline Giat Kampanye & Kampanye tentang adaptasi kebiasaan baru di Era New Normal \\
& - Media kampanye yang digunakan Stiker dan Poster (himbauan untuk \\
& 5 M) \\
Awareness & Kegiatan dilaksanakan baik luring/daring \\
& - Metode pelaksanaan door to door dan optimalisasi Sosial Media \\
& Instagram, FaceBook, Twitter atau Youtube. \\
\hline - & Pembagian berbagai produk dari Program PELITA (Masker, \\
& Handsanitizer, Sabun Cuci Tangan, bahan sembako, dll.) \\
& Ikut serta bersama ibu-ibu PKK dan Darwis dalam penguatan kegiatan \\
& kemasyarakat. \\
\hline &
\end{tabular}




\begin{tabular}{|c|c|}
\hline Kemitraan & $\begin{array}{l}\text { - Ikut berperan aktif dalam kegiatan di SATGAS COVID-19 } \\
\text { - Lahirnya kader-kader Pejuang Kehidupan yang dapat membantu } \\
\text { meringankan beban Tenaga Medis. }\end{array}$ \\
\hline
\end{tabular}

\section{PEMBAHASAN}

Kegiatan pelaksanaan Program PELITA bertujuan untuk memberikan edukasi pola hidup sehat kepada anak-anak di Kelurahan Tambakrejo. Pandemi covid-19 belum sepenuhnya usai, maka pola hidup sehat masih pada anak-anak merupakan sesutau hal yang penting supaya mereka tidak rentan terhadap virus covid-19. Disisi lain sebagian besar anakanak sudah mulai lengah dan tidak disiplin lagi dalam menjaga protokol kesehatan. Oleh karena itu penguatan akan protokol kesehatan harus terus digalakkan. Edukasi mengenai pola hidup sehat akan terus bermanfaat meskipun pandemi sudah berakhir.

Program PELITA tidak hanya fokus pada pemberian edukasi tentang protokol kesehatan namun juga mencoba memperkuat Social Awareness pada masyarakat Tambakrejo. Kegiatan program PELITA meliputi Sosialisasi Kebijakan; Edukasi $5 \mathrm{M}$; Video Tutorial Protokol Kesehatan; Optimalisasi Sosial Media; Giat Kampaye; Kemitraan; Penguatan Social Awareness.

\section{Sosialisasi Kebijakan}

Sosialisasi kebijakan tentang protokol kesehatan mampu memberikan informasi kepada peserta untuk hidup disiplin dengan protokol kesehatan sehingga nantinya dapat menekan laju peningkatan masyarakat yang terdampak Covid-19. Kegiatan sosialisasi didesain sesuai dengan pemahaman dan minat anak-anak sebagai peserta. Pada gambar 3 dapat dilihat salah satu foto kegiatan sosialisasi.

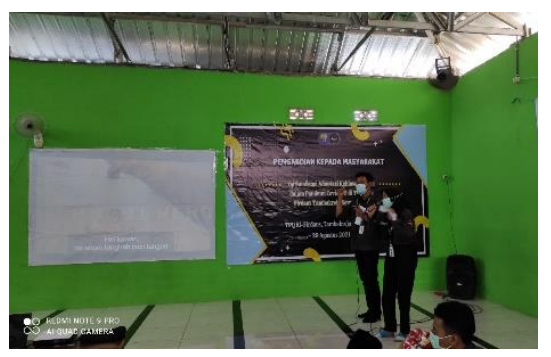

Gambar 3. Sosialisasi Kebijakan Protokol Kesehatan Kepada Anak-Anak Tambakrejo

Sosialisasi kebijakan diberikan kepada peserta kegiatan PPM khususnya anak-anak namun juga tidak terkecuali bagi warga Tambakrejo secara keseluruhan. Sosialisasi yang diberikan meliputi sosialisasi tentang panduan adaptasi kebiasaan baru di era new normal. Sosialisasi Kepmenkes No: HK.01.07/Menkes/382/2020 tentang Protokol Kesehatan di Tempat dan Fasilitas Umum, dan pengaturan tentang Penertiban dan Pengawasan.

\section{Edukasi 5M}

Berbagai upaya untuk mencegah penyebaran dan penularan Covid-19 terus dilakukan, Salah satunya dengan menyusun pendoman dan protokol kesehatan untuk menghadapi COVID-19 dan konsisten menjaga kesehatan imun dan iman. Protokol kesehatan dikenal dengan sebutan 5M. Protokol kesehatan 5M ini salah satu yang ditanamkan kepada anakanak di Kelurahan Tambakrejo. Kegiatan edukasi $5 \mathrm{M}$ dapat dilihat pada gambar 4 berikut ini.

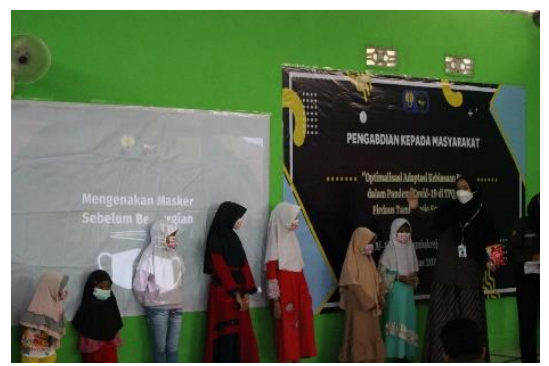

Gambar 4. Edukasi 5M kepada Anak-Anak di Kelurahan Tambakrejo 
Kegiatan edukasi 5M meliputi mencuci tangan, memakai masker, menjaga jarak, menjauhi kerumunan, mengurangi mobilitas.

\section{Video Tutorial Protokol Kesehatan}

Media merupakan salah satu faktor penting dalam penyampaian materi khususnya pada anak-anak. Salah satu media yang digunakan dalam kegiatan program PELITA yaitu media Video berisi tutorial protocol kesehatan yang dibuat sesuai dengan tingkatan kognitif anak-anak, sehingga anak-anak tertarik untuk menonton tayangan video tutorial tersebut.. Di dalam video disajikan materi secara runtut tentang cara mencucit tangan dengan benar, memakai masker, menjaga jarak, menjauhi kerumunan, dan mengurangi mobilitas. Pada gambar 5 dapat dilihat salah satu gambaran isi dari Video Tutorial Protokol Kesehatan.

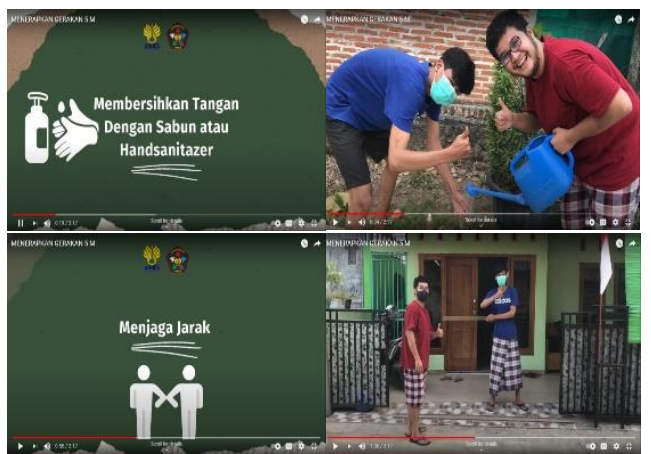

Gambar 5. Video Tutorial Protokol Kesehatan

Materi di dalam video disajikan secara menarik dan jelas dengan tujuan agar anak dapat dengan mudah memahami materi yang disampaikan. Selain itu setelah video ditayangkan, anak-anak diminta untuk langsung mempraktikan apa yang telah mereka tonton dalam video. Dengan metode demikian anak tidak hanya menerima infomasi saja melainkan juga mempunyai pengalaman secara langsung selama proses kegiatan berlangsung.

\section{Optimalisasi Sosial Media}

Edukasi protokol kesehatan juga dilakukan melalui sosial media. Optimalisasi sosial media ini sebagai sarana edukasi harapannya dapat menambah luas penyebaran informasi tentang pentingnya menjaga Protokol
Kesehatan. Meskipun program vaksinasi sudah berjalan dan kondisi sudah mulai membaik, tetapi hal ini tidak berarti penerapan Protokol kesehatan 5M dapat ditinggalkan. Media sosial yang dapat digunakan untuk sarana edukasi Protokol Kesehatan seperti Instagram, Facebook, Twitter, Youtube, Whatsapp Group dll. Pada gambar 6 dapat dilihat salah satu kegiatan penyebaran sosialisasi protokol kesehatan melalui sosial media Instagram.

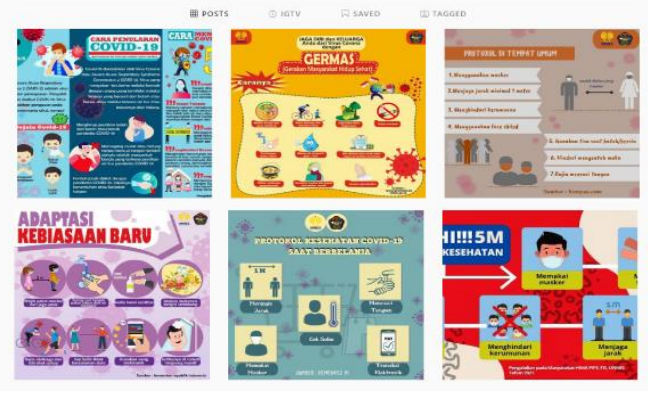

Gambar 6. Edukasi Protokol Kesehatan melalui Sosial Media

Optimalisasi sosial media sebagai sarana penyebaran edukasi protokol kesehatan bertujuan supaya penyebaran edukasi tidak hanya terbatas pada anak-anak dan warga Tambakrejo saja melainkan juga dapat menjangkau masayarakat yang lebih luas. Penyebaran melalui sosial media juga dapat menekan penggunaan waktu dan biaya. Selain itu, dengan optimalisasi sosial media, konten edukasi akan terus dapat diakses walaupun kegiatan program PELITA telah berakhir, sehingga kegiatan edukasi tidak terbatas selama program PELITA berlangsung.

\section{Giat Kampanye}

Kegiatan Giat Kampanye masih dalam satu rangakaian dari program PELITA yakni mengkampanyekan dengan berbagai cara terkait dengan protokol kesehatan. Kampanye tentang adaptasi kebiasaan baru di Era New Normal menjadi sangat penting karena edukasi protokol kesehatan tidak hanya cukup sekali dilaksanakan melainkan membutuhkan beberapa kali kegiatan untuk menanamkan kebiasaan baru pada masyarakat. Oleh karena itu dengan Giat Kampanye ini dapat memaksimalkan edukasi yang sebelumnya sudah ada. Giat kampanye 
dilakukan dengan cara memberikan informasi tentang protokol kesehatan dalam bentuk poster dan stiker. Informasi protokol kesehatan dalam bentuk Poster dan stiker tujuannya memberikan informasi kepada anak-anak maupun warga melalui media gambar atau cetak yang kemudian ditaruh ditempat-tempat umum yang strategis, sehingga masyarakat dapat membacanya ketika berkegiatan di luar rumah. Pada gambar 7 merupakan contoh media poster dalam rangka giat kampanye protokol kesehatan.

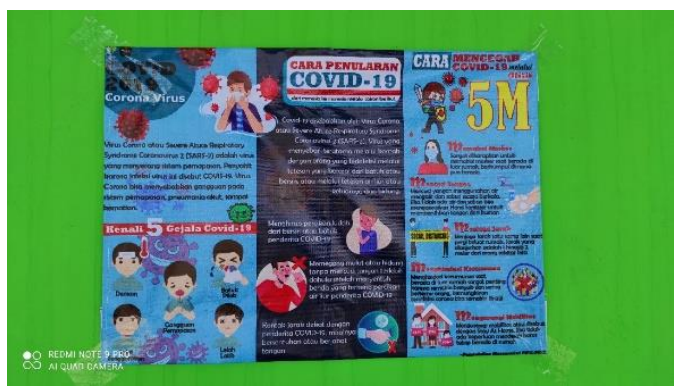

Gambar 7. Edukasi Protokol Kesehatan melalui Giat Kampanye dengan Menggunakan Poster

Selain dalam bentuk poster, kegaitan giat kampanye juga dilakukan dengan menggunakan media stiker, media stiker relatif lebih mudah dan fleksibel dalam penggunaannya, karena ukurannya yang lebih kecil dan dapat dengan mudah ditempel dimana saja, akan tetapi media stiker cakupannya lebih kecil dibandingkan media poster yang memiliki ukuran yang jauh lebih besar. Pada gambar 8 dapat dilihat kegiatan penempelan stiker tentang protokol kesehatan.

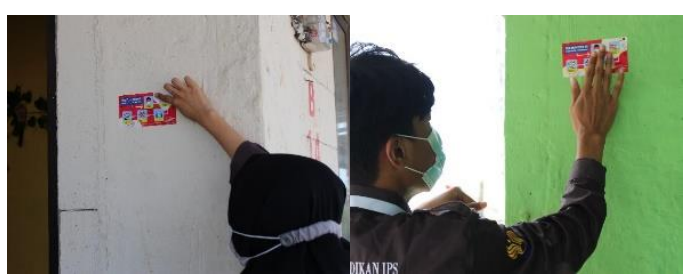

Gambar 8. Giat Kampanye melalui Stiker

Kegiatan Giat Kampanye yang dilakukan secara luring merupakan pelengkap dari serangkain kegiatan edukasi protokol kesehatan secara daring. Dengan penggunaan dua pendekatan yang berbeda baik secara daring maupun luring bertujuan untuk memaksimalkan dampak edukasi serta dapat saling melengkapi kekurangan dari masing-masing pendekatan yang digunakan, sehingga anak-anak beserta warga Tambakrejo dapat memahami dan menerapkan Protokol Kesehatan dalam kehidupan sehari-hari.

\section{Penguatan Social Awareness}

Program PELITA tidak hanya berfokus pada optimalisasi protokol kesehatan saja melainkan juga penguatan terhadap nilai-nilai sosial yang ada di masyarakat. Penguatan social Awareness menjadi hal yang sangat penting dan menjadi fokus dalam program ini. Kepedulian untuk saling membantu bagi sesama seyogyanya memang harus dilakukan terutama pada situasi dan kondisi pandemi seperti ini. Dengan adanya Covid-19 sebagian besar masyarakat merasakan dampak dari pandemi ini. Banyak warga masyarakat Tambakrejo yang membutuhkan bantuan, terlebih sebagian besar warga disana tergolong masyarakat ekonomi menengah kebawah. Melalui program PELITA dilaksanakan bakti sosial berupa pemberian masker, handsanitizer, tempat cuci tangan, sabun cuci tangan, bahan sembako, dan lain-lain yang diberikan kepada warga Tambakrejo. Kegiatan ini bertujuan untuk dapat meningkatkan social awareness yang ada di masyarakat Tambakrejo. Pada gambar 9 dapat dilihat salah satu kegiatan dalam rangka penguatan Social Awareness.

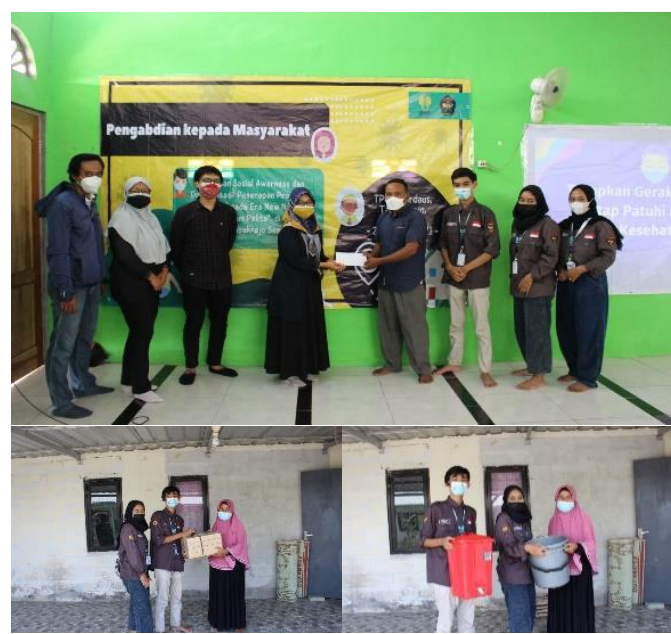

Gambar 9. Giat Kampanye melalui Stiker

Peran aktif dari anak-anak dan masyarakat Tambakrejo merupakan kunci dari program PELITA. Oleh karena itu kesadaran dari semua warga tanpa terkecuali menjadi pondasi penting 
akan keberhasilan dalam memerangi penyebaran covid-19.

\section{SIMPULAN}

Penguatan Social Awareness dan Optimalisasi Penerapan Protokol Kesehatan pada Era New Normal melalui "Program Pelita" di masyarakat Tambakrejo Semarang menjadi sangat penting untuk saat ini. Optimalisasi penerapan protocol Kesehatan masih harus terus menjadi perhatian meskipun pandemi saat ini sudah mulai membaik. Penerapan protokol kesehatan dan pola hidup sehat harus tetap dilaksanakan, meski situasi dan kondisi sudah kondusif pola hidup sehat sesuai Protokol. Oleh karena itu perlu adanya kegiatan optimalisasi penerapan Protokol Kesehatan yang dilakukan melalui Program PELITA, secara lebih rinci kegiatan tersebut meliputi Sosialisasi Kebijakan, Edukasi 5M, Video Turorial Protokol Kesehatan, Optimalisas Media Sosial, Giat Kampanye, Kemitraan dan Penguatan Social Awareness.

Saran dalam program ini yaitu perlu adanya Kerjasama dari berbagai pihak baik itu Pemerintah Kota setempat, Tenaga Kesehatan, Satgas Covid-19 dan para Akedmisi lainnya untuk saling membantu dalam penerapan Protokol Kesehatan di masyarakat. Masih banyak masyarakat yang membutuhkan edukasi betapa pentingnya untuk selalu menerapkan Protokol Kesehatan dimana pun dan kapan pun. Selain itu kedepan harapannya semua warga Tambakrejo dapat menerima vaksinasi minimal dosis pertama. Vaksin menjadi sangat penting untuk menciptakan herd imunity sehingga pandemi covid-19 dapat segera berakhir.

\section{DAFTAR PUSTAKA}

Chambers, R. 1996. Participatory Rural Appraisal: Memahami Desa Secara Partisipatif. Yogyakarta: Oxam Kanisius.

Goleman, D. 1998. Working with emotional intelligence. Bantam.

Martin. RW., Katie. B., Sara. BK., \& Noah. B. 2017. 'Development and implementation of student social-emotional surveys in the CORE Districts'. Journal: Journal of applied developmental psychology. Holland: Elsevier Inc.

Rochdyanto, Saiful. 2000. Langkah-langkah Pelaksanaan Metode PRA. Makalah ToT PKPI. Yogyakarta.

https://www.kompas.com/tren/read/2021/06/13/1 43000165/kasus-covid-19-melonjak-inipenyebab-dan-daerah-dengan-kasustinggi? page $=$ all . 